\title{
Spiritual-based Moral Value Approach in Kindergarten
}

\author{
Zakiyah \\ University of Muhammadiyah Purwokerto \\ zakiyah_ump@yahoo.com
}

\begin{abstract}
This research aimed at investigating spiritual-based moral value approach as well as finding the excellence of spiritual-based moral value approach in building the students' character. Descriptive qualitative in the form of the case study was used in this research. The data was collected using observation, in-depth interview, and documentation. The data then analyzed using some steps such as data reduction, data display, and verification. The result of the study showed that in implementing spiritual-based moral value approach, teachers started the teaching process by giving the foundation of Ilahiyah (Goddess) Orientation, tazkiyah an-nafs (cleanse the soul), showing the good character of Muslim, spiritual leadership and being professional. The teaching process was conducted integratively using some methods such as habituation and practice, exemplary, playing, storytelling, singing, and field study. These methods were conducted in some steps including apperception, discussion, storytelling, media shows, role-playing, value reflection, value stressing, and also cooperating with parents.
\end{abstract}

Key words: moral value teaching, spiritual approach

\section{INTRODUCTION}

Degeneration of children's moral value in this nation is concerned by all elements, including educators. Moreover, the Child Protection National Commission records a great number of crime performed by children, there were 2.008 cases during the first quarter of 2014 . This situation is getting worse because some of the educational institutions lack preparing children with moral values which are building children's character. Lickona [1] argues that the most apprehensive case of all the moral problems is the elevation of teenage violence.

Furqon [2] argues that the phenomenon of moral degeneration happened in the society recently is very apprehensive. The attitudes performed by young generations are badly managed. Moreover, the good attitudes are gradually diminished; the religious moral is no longer concerned. He says that the pedagogical principles take a crucial part in creating qualified generations in the future. Therefore, inserting spiritual aspects into education becomes a crucial part in resolving problems related to this nation's moral crises.

The mentioned condition above indicates how crucial moral value teaching is. It is supposed to be implemented as the core of education in Indonesia to resolve the unexpected and complicated problems encountered by this nation. The moral values are necessary to be taught to children; it is better to be taught since they are in the kindergarten. It is expected that the moral values taught will be planted deeply in the children's heart for their characters are still openly shaped and guided. In short, the moral values will positively affect their characters.

The teaching of moral values is conducted to prepare children to own good attitudes and qualified characters in the future. Salahuddin [3] says that educated people are the assets of the future. Preparing them with qualified characters and leadership is, in other words, preparing a strong-characterized human that can give good examples to the society.

Aqib [4] states that in the context of social life, children act as the important determinant for the future. It is in their hands that the development of the social life is managed. Shaping the nation's characters and the human resources is determined by how children are appropriately treated and educated in their early life.

Kindergarten children are aged 4-6 years old. As one of the early childhood educations, this institution provides early education programs for 4-year-old children up to elementary level [5]. This is the golden period because children' brain is growing and developing rapidly at this time [6]. The brain is the main factor in children's cognitive aspect.

The teaching of moral values for children in kindergarten becomes children's reference to act in the next stages of life. Apprehensively, it is known that some of the education outputs have not represented moral attitudes. Being scrutinized, this condition is closely related to the basic education in their previous years - the pre-kindergarten phase. The foundation of mental, spiritual, and moral values owned by the children may not be maximally concerned in that phase.

One of the factors believed to be the significant cause of the less-successful learning of the moral values in kindergarten is the approach which does not provide creative activities and does not accommodate children's affective aspects. Adding to the lack of success, the used approach is not fun, monotone, and is not varied. The approach only concerns on the intellectual aspects, not the spiritual ones.

The idea of developing moral value education since early childhood is basically conducted upon the facts of apprehensive education outputs which are not fully representing moral and good attitudes in children. Therefore, as an early remedy for the Indonesian 
education system, it is crucially developed a moral value education in the early childhood to strengthen children's mental and spiritual aspects. In the end, the program can shape children to own good attitudes and essential characters.

Moral values of kindergarten children as mentioned in the Ministry of Education Regulation No. 582009 [8] cover: 1 ) age $4-<5$ years (Class A) and 2) age $5-<6$ (Class B).

Teaching approach takes a crucial part to achieve the learning objectives. The approach is defined as the foundation of the learning process [9]. Teaching approach includes ethical-pedagogical contents, which go along the learning process containing spiritual, rational/intellectual, emotional, functional, exemplary, habituation and experience learning. One of the learning approaches which can be applied in the learning of moral values in kindergarten is the spiritual approach. The approach is related to the religious worship to create professional teachers in learning.

The spiritual approach focuses on the tazkiyatunnafs (self-sanctification). Rohana [10] argues that spiritual education is meant to build a worshipful person that admits the existence of God the Creator and to reveal physical potential to be a khalifah (leader).

Spiritual-based teaching [11] is derived from a belief that learning activities are kind of worshipping Allah. The implementation of moral value teaching in Kindergarten is as follow.

\section{METHOD}

This research applied the descriptive qualitative approach to the case study in TK (Kindergarten) Aisyiyah I Purwokerto and TK Universitas Muhammadiyah Purwokerto. Sources of data were both primary and secondary data sources. The data were validated through data triangulation. The data were collected through observations, in-depth interviews, and documentation. The data were analyzed through three cycles which happened at the same time such as (1) data reduction; (2) data presentation; and (3) conclusion \& verification [12].

\section{RESULTS}

\section{Spiritual-based Moral Value Approach in TK Aisyiyah I Purwokerto}

The philosophy of the importance of moral values learning in TK Aisyiyah I 2015-2020 is based on the followings: QS. An-Nisa' : 9; QS. Luqman : 12-16; QS. At-Tahrim : 6; QS. Al-Kahfi : 46; and QS. Al-Nahl : 78; and Hadiths about sanctification.

The curriculum of moral values teaching in TK Aisyiyah I Purwokerto is based on the competencies as follows: (1) local curriculum (Religion/ Kemuhammadiyahan-Keaisyiyahan); (2) Religionintegrated national curriculum; and (3) local culturebased curriculum. In short, the curriculum covers the introduction of the existence of Allah, the procedures of worshipping God, and the habit of good attitudes.

The implementation of moral values teaching through the spiritual approach covers the concept of educating children with passion, loyalty, patient, and worship. The teachers teach the children fully and the children learn happily. The teachers also implement the spiritual leadership and become the good model (uswahkhasanah) for the children in every behavioral matter. The children are easily imitating what the teachers do.

The teaching process is conducted integrally to the themes such as (1) routine activities; (2) spontaneous activities; (3) exampling activities; and (4) programmed activities. Moreover, there are also evaluations. The teaching process is also conducted through some steps namely: (1) apperception; (2) discussion; (3) sharing; (4) role play; (5) the use of learning media; (6) value reflection; (7) value implementation; and (8) follow-up activities.

The methods used in the school covers (1) training method and habituation to shape children's characters; (2) playing method; (3) sharing stories; (4) modeling method (uswatunkhasanah); (5) sanctification method (tazkiyah an-nafs); and (6) singing method.

The teaching of moral values in the school involves parents by conducting the monthly meeting and having cooperative and intensive communication. The learning evaluation by recording children's moral values in each meeting is done based on the learning indicators. Besides, teachers also fill in the checklist form to record the development of children's moral values holistically.

\section{Spiritual-based Moral Value Approach in TK Universitas Muhammadiyah Purwokerto}

The philosophy of moral values teaching in TK Universitas Muhammadiyah Purwokerto is begun with the awareness of the school's founders of the importance of moral values for early childhood to succeed in their future. Moreover, the school was built because at that time there was no similar institution focusing on moral values approach.

The curriculum of moral values teaching in the school applies the 2013 Curriculum added by local curricula such as Religion and Banyumas Language. The 2013 Curriculum covers the Core Competency and the Basic Competency. The Core Competency is a description of standardized goals of children's development in the end of early childhood education. It is formulated as follows: (1) Core Competency of Spiritual Attitude (KI-1); (2) Core Competency of Social Attitude (KI-2); (3) Core Competency of Knowledge (KI-3); and (4) Core Competency of Skill (KI-4).

The lesson plans are based on the Semester Overview Program (PROMES), Weekly Overview Program $(R P P M)$, and Daily Overview Program $(R P P H)$. The lesson plans are then implemented in the form of activities namely Basic Competency $(K D)$, learning materials, learning indicators, learning activities, and learning assessment. 
The implementation of moral values through the spiritual approach in TK Universitas Muhammadiyah Purwokerto is also begun with teachers' intention to worship Allah loyally. The teachers intend to lead the children spiritually. Moreover, they want to give good examples to children in all aspects of attitudes.

The implementation of moral values teaching through the spiritual approach in the school covers learning by doing, learning by playing, learning by the process, and integrated learning. All of them are initiated by teachers that apply the moral values in their daily life.

The evaluation is conducted by note-taking recording children's attitudes in their daily lives. The notes are recorded narratively showing children's success in doing activities. The assessment is conducted through observation, assignment, performance, anecdotal record, dialogue, parent report, children portfolio, and children profile description. The results are then informed to parents at the monthly meeting and the semester report distribution.

The Foundation of Spiritual-Based Moral Value Approach in TK Aisyiyah I dan TK Universitas Muhammadiyah Purwokerto

Approaching children's inner aspects; the approach uses self-sanctification method which is oriented to God, accommodative, and touching; Making a close relationship with teachers; Showing concrete examples of conducting good attitudes; Moral building on children's awareness of implementing moral values; Involving children's activeness in learning; and Providing holistic and integrated approach which makes children understand moral values deeper.

\section{DISCUSSION}

Children aged 4-6 are in the sensitive period of logical aspects development. They start to receive varied development of all the potentials possessed. The sensitive period is when both physical and mental functions are ready to respond to stimuli from the environment and are shaped to assimilate or internalize it into themselves. This period is the beginning of the physical, cognitive, language, social emotion, selfconcept, discipline, independence, art, moral, and religious values development. Therefore, it needs conditions and stimuli which suit their needs to optimize their growth and development.

Teachers in kindergarten are always observed, heard, and imitated by children. Moreover, non-selective imitations happen because the children cannot yet differentiate good and bad attitudes. The imitations will later be knowledge and experience which become children's foundation to act in the daily life. According to this condition, teachers in kindergarten must be good examples to children regarding the daily attitudes.

As a leader in teaching moral values to children, a teacher must have spiritual leadership skill. Tobroni [13] argues that spiritual leadership brings both world and
God dimensions. A teacher possessing spiritual skills will show professionalism, totality, loyalty, patience, and risk-taking attitudes in her/his teaching.

Munir [14] states that a teacher possessing spiritual skills is (1) showing dedication and love towards the profession; (2) always ready to conduct his/her job as a teacher; (3) always showing his/her best performance; (4) more listened by the students; (5) loved by the students; and (6) giving his/her students' maximum effort.

The teaching of moral values in kindergarten is urgent to conduct [15]. The basic moral which should be acquired by children will be their foundation for the next stages of life. Adding to this, Lickona [1] suggests three components of good character education, namely moral understanding, moral feeling, and moral action.

The results of the research show that the teaching of moral values through the spiritual approach in TK Aisyiyah I Purwokerto and TK Universitas Muhammadiyah Purwokerto is begun with the following activities: (1) God-oriented teaching; (2) selfsanctification; (3) Muslim characteristics; (4) spiritual leadership; and (5) professionalism.

Habit, practice, good exemplary and selfsanctification methods are in line with al-Ghozali [16]. Self-sanctification (tazkiyatunnafs) method becomes teachers' reference to teach moral values. It is quite different from [1] who says that in character education, it is crucial to concern on the importance of three components of good characters such as moral understanding,moral feeling, and moral action. The theory does not relate the aspects of God in the learning process. It tends to lack spiritual aspects, which are the core of education, in building the children's moral values.

\section{CONCLUSION}

Spiritual-based Moral Value Approach in TK Aisyiyah I Purwokerto and TK Universitas Muhammadiyah Purwokerto is begun with spiritualbased activities. Teachers teach with (1) the intention of worshipping Allah (Ilahiyah); (2) the self-sanctification (tazkiyah an-nafs); (3) the reflection of Muslim characteristics; (4) the spiritual leadership; and (5) the professionalism.

This research strengthens Al-Ghazali's theory of alThuruq 'ilaTahdhib al-akhlaq about habituation, exemplary, and tazkiyahan nafs methods. Moreover, it adds Lickona's theory, which concerns on the importance of three good characters: moral knowing, moral feeling and moral action which are based on spirituality.

\section{REFERENCES}

[1] Lickona, Thomas, Pendidikan Karakter, Bandung, Nusa Media. 2013

[2] Furqon. Kembangkan Pendidikan Berbasis Agama. Republika. 2016 
[3] Salahuddin, Anas \& Alkrienciehie, Irwanto. Pendidikan Karakter, Pendidikan Berbasis Agama \& Budaya Bangsa, Bandung: Pustaka Setia. 2013

[4] Aqib, Pedoman Teknis Penyelenggaraan PAUD (Pendidikan Anakusia Dini, Bandung ; Nuansa Aulia. 2011

[5] Masitoh ET AL. Pendekatan Belajar Aktif di Taman Kanak-Kanak. 2015 Departemen Pendidikan Nasional, Direktorat Jendral Pendidikan Tinggi,Jakarta

[6] Suyadi, Psikologi Belajar PAUD, Yogyakarta: PT Pustaka Insan Madani. 2010

[7] Hidayat, Pendidikan Anak Usia Dini, Jakarta: Pustaka belajar. 2007

[8] Permendiknas Nomor 58 Tahun 2009, tentang Standar Pendidikan Anak. Usia Dini

[9] Sanjaya, Wina, Strategi Pembelajaran Berorientasi Standar Proses Pendidikan, Jakarta: Kencana Prenada Media. 2010

[10] Rohana, Pendidikan Spiritual,Jakarta, Bumi Aksara. 2010

[11] Rivauzi, Ahmad, (2007), Pendidikan Berbasis Spiritual; Tela'ah Pemikiran Pendidikan Spiritual Abdurrauf Singkel dalam Kitab TanbihalMasyi, (Tesis), (Padang: PPs IAIN Imam Bonjol Padang, 2007)

[12] Miles, M.B., dan Hubermen, A.M, Analisis data Kualitatif, (Tarj). Tjetjep Rohidi dan Mulyarto, Jakarta: Universitas Indonesia Press. 2003

[13] Tobroni, The Spiritual Leadership, Malang : UMM Press. 2012

[14] Munir, Abdullah, Spiritual Teaching, Pustaka Insan Madani. Yogyakarta. 2009

[15] Ulwan, Nashih. Abdullah, Tarbiyatulaulad fi Islam, PenerbitAsy-Syifa', Semarang. 1981

[16] Al-Ghazali, Abu Hamid Muhammad, Ihya'Ulum aldin, Beirut : Dar al-Fikr, Jilid III. 1989 